\title{
Obituaries
}

\section{Dennis Gath}

Psychiatrist who carried out important studies on postnatal depression and community care

In 1996 the BMJ organised an exhibition of photographs of leading British doctors at the National Portrait Gallery. The title of the exhibition, With Head and Heart and Hand, indicated that these were doctors who combined intellectual rigour, clinical skill, and compassion. Psychiatry was represented by Dennis Gath. The photograph showed him on a bridge in Oxford, appropriately symbolic of his achievements in linking psychiatry with the other specialties of medicine, and medicine with the other faculties of the university.

Dennis Gath joined the newly established Oxford University department of psychiatry in 1969, remaining there until his retirement in 1996. He carried out a systematic series of studies of the relationship between physical conditions and psychological disorders. At that time, most studies of this relationship had been inconclusive or misleading because of limitations of design and method. Dennis Gath introduced reliable methods of assessment and measurement, and an epidemiological framework, and thereby overturned many of the previous conclusions. He also carried out important studies of depression after childbirth, which showed it to be common and indicated how it should be treated.

With the growth of community care in the 1980s, Dennis Gath began a series of studies of its outcomes. The first concerned the treatment, in general practice, of minor

\section{Advice \\ We will be pleased to receive obituary notices of around 250 words. Pressure on space means that in most cases we will be able to publish only about 100 words in the printed journal, but we can run a fuller version on our website. We will take responsibility for shortening. We do not send proofs. Good quality, original photographs are welcome. Please give a contact telephone number and, where possible, supply the obituary on a disk or by email to obituaries@bmj.com If sending a picture electronically, please attach as a jpeg or a tiff rather than as part of a Word document. We need to know the year of birth and exact date of death of the deceased, and we prefer obituaries to state the cause of death. Please spell out abbreviations.}

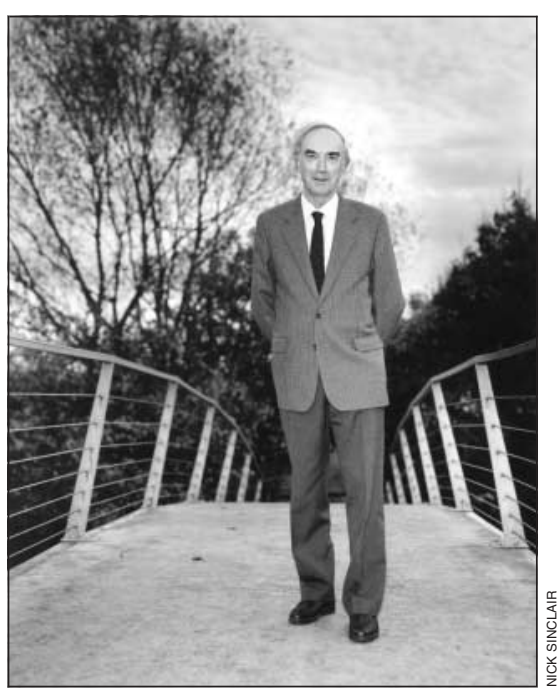

mood disorders. Working closely with general practitioners he and his research team showed that many patients with these disorders recovered without medication. $\mathrm{He}$ showed that the others could be treated effectively with an uncomplicated form of counselling that he called problem solving; this could be provided effectively by general practitioners and practice nurses. These studies of the care of patients with less severe psychiatric disorders were complemented by studies of people with the most severe disorders, including homeless people with mental illness, and those receiving the care programme approach. These studies, like all his research, had practical outcomes.

This productive programme of research was only a part of Dennis Gath's contribution to Oxford psychiatry. He played a major part in developing teaching in psychiatry for medical students and training for postgraduates. As a co-author of the Oxford Textbook of Psychiatry, his wide knowledge and the exceptional clarity of his writing were major constituents of the book's success. He served on the medicine board of the university; he represented medicine on its general board; and he was chairman of the student health committee. Outside the university, the Medical Research Council, the Department of Health, the Royal College of
Psychiatrists, and the US National Institute of Mental Health all sought his advice.

Dennis Hanson Gath was born in 1930. He entered Cambridge to read classics but changed to philosophy and psychology. After graduation, he decided to follow a growing conviction that his life should be in medicine, and he moved to Oxford for preclinical studies.

He initially thought of a career in hospital medicine, and obtained the MRCP. However, his growing interest in the personal side of medicine led him to psychiatry, and to the Maudsley Hospital.

At the Maudsley, Dennis Gath trained with Sir Aubrey Lewis, who insisted that his trainees should study the life and personality of each patient in the same fine detail as they studied the scientific basis of the illness and its treatment. It was an approach that fitted well with Dennis' background in science and the humanities, and one that guided all his subsequent practice and teaching. At the Maudsley he also learnt the techniques of epidemiological research, which were to inform his subsequent inquiries.

Dennis Gath was a sociable man. $\mathrm{He}$ enjoyed good company, good conversation, and good food and wine. He enjoyed music, the theatre, and long walks in the countryside, especially in France. $\mathrm{He}$ was an excellent companion, good natured, interesting, and interested in others. He was also a most generous and loyal friend.

In 1973 he was elected fellow of Wolfson College, and he enjoyed and played a full part in the intellectual and social life there. When he retired from his university post in 1996, he looked forward to a continuing involvement in college life and in the intellectual and cultural activities that abound in Oxford.

None of this was to be. The onset and relentless progression of Alzheimer's disease prevented Dennis from achieving his goals. He died from an intercurrent infection.

Divorced from his first wife, Anne Lewis, he leaves his second wife, Eileen Curl; three children; eight grandchildren; and two stepchildren and their five children. [MICHAEL GELDER]

Dennis Gath, clinical reader in psychiatry Oxford University (b 1930; q Oxford 1959; DM, FRCP, FRCPsych), d 14 May 2005. 


\section{Margaret Winifred Anderson}

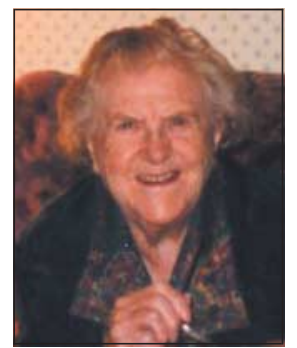

Former obstetrician and gynaecologist Kathmandu, Nepal (b Glasgow 1904; $q$ Glasgow 1929), d 26 March 2005.

Win Anderson went to India in 1932 to work with the Zenana and Bible and Medical Mission. In those days Indian women could not be seen by male doctors and there was a need for female doctors to bring medical care to women. Win worked in Patna as an obstetrician and gynaecologist, and was there throughout the second world war. In the mid-1950s she went to work in Kathmandu with the United Mission to Nepal. This non-denominational group helped to develop educational, technical, agricultural, and medical services. Win helped with medical relief in Bangladesh for two or three years after the devastating cyclone and civil war in 1970-1. She worked in Pakistan on two occasions in the late 1970s. She never married. [MARGARET K BANCEWICZ]

\section{Janet Queen (“Jenny") Ballantine (née Morton)}

Hospital doctor Roadmeetings Hospital, Braidwood by Carluke, 1960-79 (b 1916; $q$ Glasgow 1947), died from pneumonia and dementia on 5 April 2005.

Jenny decided to study medicine after nine years as a librarian. She spent some time working in Ayrshire and arrived at Law Hospital, Carluke, in 1949. In 1950 she transferred to the sanatorium and in 1951 married her boss. In 1960 she became medical officer at Roadmeetings Hospital, Braidwood by Carluke, where she was in daily charge of four wards of long stay patients, mainly with multiple sclerosis, but also some with psychogeriatric probliems. Jenny was involved in setting up three branches of the MS Society in Lanarkshire and received the MBE from the Queen in 1977 for her services to long stay patients. She retired in 1979. Predeceased by her husband, Ian, she leaves a son. [John M BaLlantine]

\section{Edward Charles Arden Bott}

Former private general practitioner London and chief medical officer Metropolitan Police ( $b$ London 1924; q Cambridge/London 1949; CBE, FRCP), d 1 April 2005.

Ted was house physician to Dr John Richardson (later Lord Richardson) at St

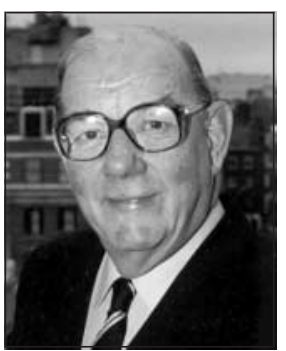

Thomas's Hospital, London, and, on his return from national service in Cyprus, he returned to St Thomas's. At that time advancement in the NHS was extremely slow and so he entered private general practice. His friendship with John Richardson led him into close contact with politicians and the security services. It was then that he was appointed chief medical officer to the Metropolitan Police in 1980. Ted was an excellent bridge player and also a good Cresta rider in St Moritz. He died after a fall when he dislocated both hips and developed hepatic encephalopathy, pneumonia, and bleeding from a prepyloric ulcer. He leaves a wife, Veronica; two sons; and six grandchildren. [JAMEs BeVAN]

\section{David Christopher Simmonds Gough}

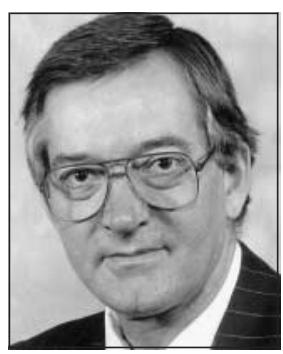

Consultant paediatric urologist Royal Manchester Children's Hospital, Pendlebury, Manchester (b Bristol 1947; q Liverpool 1969; FRCS, FRACS, DCH), d 29 March 2005.

David became a leading figure in paediatric urology. He developed a special interest and expertise in congenital abnormalities of the lower urinary track, particularly bladder exstrophy. He was an enthusiastic proponent and a founder member of the British Association of Paediatric Urologists. David did his house jobs at Broadgreen Hospital and then embarked on his surgical career training initially in Cambridge and Cardiff, where he developed his interest in paediatric surgery. He then spent some two years at the Royal Melbourne Children's Hospital before obtaining his appointment at the Royal Manchester Children's Hospital. Cars were a lifelong passion, to which he added collecting art and enjoying good wine. He leaves a wife, Elizabeth, and three children. [Peter Doyle]

\section{Ian Alexander Porter}

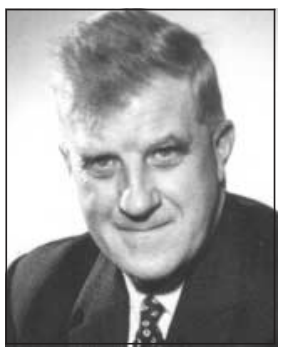

Consultant microbiologist Aberdeen 1968-83 (b 1921; q Glasgow 1945; MD, MRCPath), d 9 January 2005.

Ian was called up for national service soon after his graduation in 1945 and served as a medical officer in the Royal Air Force until 1948, when he began his bacteriological studies in Glasgow. After posts in Aberdeen, Glasgow, and Newcastle upon Tyne, in 1964 he was appointed consultant bacteriologist to Ayrshire Area Laboratory Services. He returned to Aberdeen in 1968 as consultant microbiologist and rose to consultant-incharge at the City Hospital laboratory in 1978. He was a founder member of the College of Pathologists. Ian's other main interest was writing, and his output included $A$ Short Textbook of Medical Microbiology. He leaves a wife, Doris. [Graeme Taylor]

Jean Mary Scott (née Lewis)

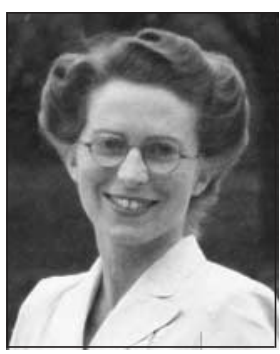

Former assistant paediatrician St Peter's Hospital, Chertsey ( $b$ Wolverhampton 191 7; q Birmingham 1940;DCH), d 6 May 2005.

Jean was a captain in the Royal Army Medical Corps in 1943 and saw service in India and Malaysia as a medical specialist. She was demobilised in 1947. She started the blood transfusion service in Penang and then worked for the Singapore AntiTuberculosis Association before returning to England in 1962, where she was assistant paediatrician at St Peter's, Chertsey, and the White Lodge Centre. After retiring from the NHS she worked at the Charles Johnston Hospital, Nqutu, Zululand. Predeceased by her first husband, Angus, and her second husband, John, she leaves three sons; a stepson; and six grandchildren. [WILLIAM Scoтt]

Longer versions of these obituaries are available on bmj.com 